\title{
What is the Level of Customers' Trust in the Safety of Food and Beverage Labels at Egyptian Hotels?
}

Mohamed T. A. Abdelmawgoud ${ }^{1}$;

Wael Mohamed Abdelnaby*;

${ }^{1}$ Faculty of Tourism and Hotels- Minia University, ${ }^{2}$ Faculty of Tourism and Hotels-Beni Suef University

\begin{abstract}
The aim of the current paper is to investigate the level of customers' trust in the safety of food and beverage labels at Egyptian hotels. Descriptive approach was used. Data was represented by customers' opinions through a questionnaire. There is a difficulty in identifying the members of the population. Therefore, it is suitable to choose a non-probability sample such as a convenience sample. The stratified sample has included 492 tourists who visited the hotels of Cairo, Luxor and Aswan in Egypt. The findings revealed that the overall evaluation of customer's trust in foods served at the hotels of Cairo, Luxor and Aswan came at a high level (4.04) and SD=0.14. Therefore, the coefficient of variance is $0.03 \%$. In addition, the customer's trust is significantly different according to city, nationality, gender, age, marital status, and educational level at a significant level (0.05), while there is no statistically significant difference according to the family size factor. Moreover, the customer's trust is significant correlated with the perceived quality $(r=0.794)$, behavioral attitudes $(r=0.104)$, subjective norms $(r=0.426)$ and perceived behavioral control $(\mathrm{r}=0.192)$. There is no significant correlation with behavioral intention. Finally, there is a positive correlation between customers' purchase intention and subjective norms $(r=0.126)$. Finally, the paper concludes with a set of recommendations including Egyptian hotels dependence on food products from accredited international organizations, increasing organic foods, and merging them in the hotel's marketing plan.
\end{abstract}

Keywords: Customer Trust, Food Labels, Perceived Quality, Behavioral Intention, Subjective Norms, Perceived Behavioral Control.

\section{Introduction}

Food safety constitutes a vital issue for customers, where previous studies have shown that foodborne illness affects an estimated $30 \%$ of people every year worldwide. Thus, meals prepared outside the home represent a risking factor to be infected by these diseases, as nearly $70 \%$ of the institutions tracked are involved in these diseases (Chapman et al., 2010). Moreover, food safety is considered a major factor in monitoring food labels during the process of food product purchases. Thus, food product labels provide cutomers with food safety information (Bandara et al., 2016). Many food products specified for daily consumption contained toxic substances (Zhou et al., 2017). Various food scandals have swept the whole world, e.g., horsemeat has been used as beef and contaminated eggs and spinach have been used (McCarthy, 2018). Food consumption has a major impact on the environment, individuals, and public health (Nguyen et al., 2019). Thus, the growth of diet-related diseases has become a concern and a challenge in a more sustainable society. This led to the development of important trends in food consumption, especially the growing demand for food with natural character (Tóth et al., 2020).

The concept of customer's trust, from an organizational perspective, is a psychological state comprising the intention to accept vulnerability depending on positive expectations of the intentions regardless of anything more (Rousseau, 1998). Labelinsight (2016) arued that customers do not trust the way in which current brands provide them with product information, approximately (37\%) of customers are willing to change brands if their current brand does not provide them with the product information they are looking for. Likewise, McCarthy (2018)

\footnotetext{
${ }^{*}$ Corresponding Author, Wael Mohamed Abdelnaby, Beni Suef University.
} 
stated that food scandals negatively affected the customer's trust in the food and beverage industry, as $94 \%$ of American customers have acknowledged that they will be loyal to manufacturers that adopt full transparency Accordingly, many food product scandals have broken out in China. As a result, customer trust in the quality of food products produced or manufactured in China has declined, which in turnhas led to a market crash. Finally, the certification of food products is an authorized source of information on the market. According to this, consumers can perceive the quality of the food product (Wang et al., 2020).

Customers are interested in food labels to obtain product-specific information. When deciding whether to buy a nutritional product for the first time, $89 \%$ of shoppers staed that they always look at the price, while $80 \%$ preferred the brand name, $66 \%$ favored health claims, $68 \%$ for preservative or additive type, and 38\% preferred organic claims (FMI, 2003). Two-thirds of customers said that they read labels on foods and drinks, 34\% choose foods based on their nutritional content, and 27\% determine their choice on the food guide pyramid (Sloan, 2003). Customers are turning to healthy foods. Previous studies have shown that only $28 \%$ of customers will pay more for low-fat foods, and $15 \%$ for organic foods (IRI, 2003). There has been a rapid rise in the global consumption of organic foods over the past years (Chu, 2018). Sustainable labeling is an important tool in raising awareness and informing potential buyers on environmental, economic, and social issues (Kaczorowska et al., 2019). Organic farming is one of the most sustainable and acceptable production systems in terms of sustainability (Pércsi \& Fogarassy, 2019).

Based on the previous analysis, the spread of food scandals worldwide created a sense of anxiety and distrust among customers in food and beverage establishments. In this regard, many studies have been conducted in various countries including China. Despite the seriousness of this issue, there is no study conducted in Egypt that determined the level of customer's trust in the food products offered in Egyptian hotels. This is considered a research gap worth studying. Consequently, the siginificancw of this study is represented in the point that identifying the level of customer's trust in food products enables institutions to set controls that help meet customer expectations regarding food quality and safety. Therefore, it, contributes to maintaining customer's health, achieving his/her loyalty to the organization and achieving a competitive advantage. Finally, the current research posed the following main question" What is the level of customers' trust in the safety of food and beverage labels in the Egyptian hotels?"

\section{Literature Review}

The majority of the previous studies discussed below focus on the issue of food labels, the level of customer's trust in these labels, and their impact on the intention to purchase. Chaaban (2012) stated that the trust and quality of food are the vital variables that customers take into account when purchasing foods.similarly, Food labeling enables customers to know further data regarding the kind of foods they purchase and to make nutritionally appropriate choices (Basarir $\&$ Sherif, 2012). Accordingly, this instrument is often required when presenting or introducing a new food product such as genetically modified food (Mandle et al., 2015). Furthermore, it is an effective tool to protect customer health by food safety and to promote nutritional well-being. Labeling laws prevent fraud and misleading information, which protects consumers (FAO, 2016). In the study of Shangguan (2016) it was revealed that food labeling reduces customer dietary intake of selected nutrients and influences industry practices to reduce product contents of sodium and artificial trans-fat. The food industry is customer-oriented and it requires a faster response time to deal with food incidents. There is an urgent need for good traceability systems to help the supply chain partners to minimize production and the distribution of unsafe or poorquality products (Saad et al., 2016). Overall, customers expect food producers will provide not 
only high quality but safe food as well. This means that safety is vital for all links in the sales chain of hospitality institutions (Tuv-Nord, 2020).

Customers are aware of an industrialized food system and its consequences in a great way, as they are seeking alternative food sources such as organic, natural, sustainable, and local foods (Lang \& Lemmerer, 2019). Vecchio \& Cavallo (2019) have stated that the continuous increase in some factors such as, consumption of foods outside the home; consumption in restaurants and incidence of chronic diseases related to nutrition (overweight, obesity, hypertension, type of 2 diabetes, stroke and other non-communicable diseases) represent the main elements that raise customers' health awareness. Therefore, customer's trust is a vital element in the functioning of any market, particularly in the food and beverage sector. Food safety incidents and changes in food production practices have simultaneously led to a decrease in customer's trust and his/her need for greater trust. A previous research developed a valid and reliable consumer trust toolkit which can be used to measure trust in specific aspects of the food system (Benson, 2020). Furthermore, Sultan et al. (2020) examined the gap between the perceived behavior theory in consumers and the perceived behavioral control gap in food products, where it has depended on a sample from the internet and was limited to organic foods (Vegetables certified as safe and the impact of customer worry about vegetable safety. In addition, there is a direct effect among brand trusts as it acts as a mediator between system trust and trust in the safety of safe vegetables (Ngo et al., 2020).

Food labeling serves as a direct, accessible, and consistent manner to encourage informed food choices at the point of purchase (Kim et al., 2018). The vital role of customer's trust, which positively affects attitudes toward the purchase of convenient food products label, is represented in safe and eco-friendly attributes, and it negatively affects consumer concerns around health impacts aspects and practices in relation to environmental aspects (Ricci et al., 2018). The quality and food safety indicators are the information labels by which the degree to which customers considers the message as current, preciseness, good, and useful is determined. Service providers can improve their fame and position by offering high detailed label information (Kang \& Namkung, 2019). Customer experiences of real-life trust breakdown and recovery depend on some factors such as honest label, absence of further transgressions, positive personal experience with the retailer, the retailer's normal functioning, the normal behavior of other customers and the three contextual conditions represented in the passage of time, institutional context, and immediate trust repair strategies (Božič et al., 2020 ).

Konuk (2019) presented several factors influencing customers' trust and increase attention in the food industry as follows:1) food trade labels;2) health consciousness;3) the growing amount of socially sensitive consumers;4)consciousness for fair consumption;5) environmental concern;6) consumer innovativeness, and7) impact on consumers' willingness to buy and willingness to pay Likewise, Le et al. (2020) identified factors determining customer's trust in; food safety include labeling, location of production, store reputation, government certification, the brand composition of friends, price, the appearance of the product, packaging, age, and income. Hospitality research has shown that attitude and behavioral outcomes of the customer's trust are based on the demographic characteristics and the nationality of customers (Al-Ansi et al., 2020). Criticism is emerging in the hospitality industry due to some controversial sectors such as casinos that provide gambling opportunities, and fast-food restaurants that serve food that causes obesity. This necessities the need for involvement in corporate social responsibility for restaurant activities that may enhance brand recognition and loyalty, particularly in hospitality field. Consequently, providing healthy meals and accurate information to consumers have become determinants in brand success and the social responsibility of the hospitality industry (Rhou, 
2020). Peters (2020) has noted that one of the factors that affect the choice of menus by customers dish is the healthy option that is based on individuals' mindfulness toward selecting a dish containing detailed labels about food.

Customers are concerned with food and beverage product labels due to the following factors such as safety, origin, purity, taste, freshness, and price, which significantly differ among food types and countries. For instance, price features in Japan in a prominent way, however, respondents generally considered it as less important in other countries. Freshness for milk and taste for wine were seen as important things across all countries. Origin was considered to be at low importance in all countries across all food types (Rupprecht et al., 2019). Psychological aspect of customers, in terms of the presence of distinguished brands and the absence of others, plays a vital role in consumers' purchasing intentions explained by the consumers' level of trustworthiness in a brand. Because consumers have repetitive experiences with brands, the history with a specific brand helps customers to embrace the brand and to form a close relationship with its symbolic meanings. One of these symbolic meanings is the sense of trust and security in one's food evaluations, even in the presence of a warning from a nutritional label about an unhealthy ingredient (Vizcaíno \& Velasco, 2019). Customers' use of menu labels as a preventive health behavior and the health belief model applying in order that they can determine the health belief factors that influence customers' use of menu labels (Jeong \& Ham, 2018).

Previous studies have shown that unemployed individuals who pay much interest in nutrition during shopping and follow dietary guidelines are more likely to use food labels. In addition, education has a positive effect on the likelihood of using labels at home (Nayga et al., 1998). Moreover, the increased appeal of product label is critical to success (Sloan, 2003). The poster greatly affects purchasing decisions (Prathiraja \& Ariyawardana, 2003). For example, Chinese consumers prefer eating foods that are certified in China (Yin et al., 2010), and they do not trust other food products even if they are distinct (Xiong et al., 2011. Chen and Chen (2011) stated that the overall reliability of service providers have an important component of perceived quality and have a direct impact on the intention to purchase. Dissemination of food safety information is an effective intervention tool that positively affects food safety behaviors for food processors (Chapman et al., 2010). In this regard, UK consumers associate some of the benefits of food with organic foods, which prefer their logo more than European Union logo (Gerrard et al., 2013). Social and economic factors, ranging from the level of income to the number of family members, are important in influencing consumers' intention to buy (Yu et al., 2013). Obvious, trust is associated with reliability (Daugbjerg, et al., 2014). Therefore, consumers mainly choose approved products because they think they are healthier and tastier (Xie et al., 2015). Enhancing the emotional component of consumer decision-making and improving the level of consumer awareness of the environmental signs of seafood can stimulate more environmentally friendly seafood consumption (Jonell et al., 2016). Consumers prefer to have information about the food they consume, as well as their openness using innovative digital channels to access this information (Labelinsight, 2016).

The majority of consumers tend to check labels while purchasing to assess the suitability of a nutritional product for vegetarians, for religious reasons, to avoid food-related diseases and to check whether the food is organically grown or not. Bandara et al.'s (2016) study elobrated that Complex lifestyles, brand loyalty, and the complex nature of food labels were the main reasons why food labels were not checked (. Customers' more positive behavior towards organic foods would further enhance their purchasing intentions, while there was no significant effect on the marketing and communication price on consumer attitudes toward organic foods (Chu, 2018). Consumers' concerns regarding the environment, health, food safety, and knowledge of organic 
foods have all significantly affected their attitude towards the purchasing behavior of organic meat (Nguyen et al., 2019). As the slogan is unknown, consumers with positive attitudes toward sustainability do not use it as an indicator when shopping for food (Kaczorowska et al., 2019). Younger millennial (24 to 28 years old) are more likely to lean towards product messages like "Made with real ingredients"; "all 100\% natural"; "without added sugar"; "organic" and "without additives or Preservatives". While older adults (65 years and over) are more likely to be attracted to nutritional elements and tangible items such as "no added sugar" or "without added salt" or "no artificial preservatives" and "no additives or preservatives" (Nunes, 2019). Trust and income are among the most influencing factors on consumer intent (Bai et al., 2019)

The desire to pay for fish products is related to gender, marital status, mass communication, environmental features, hunter community, and storehouse, along with information from environmental markers. Specifically, the females seemed very responsive to the environmental signs of seafood, and their preferences were communicated to the environmental aspects along with a strong drive to protect marine habitats. Seafood environmental labels can increase consumers' desire to pay between $16 \%$ and $24 \%$ more for the product (Vitale et al., 2020). Fruit juice with a natural characteristic is preferred over enriched juice, and there is a common feature behind the perception of the two characteristics, health. Based on the natural fruit juice property, these results open up space for local production in gardens or on small and medium-sized farms. This can have beneficial effects, both for the sustainable development of rural areas and for the promotion of healthy diets towards sustainable food consumption (Tóth et al., 2020). A study revealed that the proposed additional construct, i.e. perceived quality, as well as the traditional constructs, i.e. behavioral attitude, perceived behavioral control, and subjective norm, have significant impacts on consumers' purchase intention. In addition, Chinese consumers hold different levels of trust in different labels, depending on the food certifying body, and those international bodies receive the highest confidence level (Wang et al., 2020).

\section{Methodology}

Despite the importance of Egyptian foods, there are no researches, which investigated the customers' trust in Egyptian foods. Consequently, the gap of this research is represented in exploring the level of customers' trust in the safety of food and beverage labels at Egyptian hotels. Therefore, this study depends on the descriptive approach. The research data is represented by customers' opinions about Egyptian foods through a questionnaire distributed in the hotels of Cairo, Luxor, and Aswan. There is a difficulty in identifying the members of the population. Therefore, it is suitable to choose a non-probability sample such as a convenience sample. The stratified sample has included (492) tourists who stayed at the hotels of Cairo, Luxor, and Aswan during 2019. This allows including high and low-income customers and selecting customers with some knowledge and experience in certified food in this sample. The current study used the model of customer's trust in food certification that is designed by Wang et al., (2020) for formatting the research questionnaire. This model has consisted of five grades ranging from one to 5, as (1) indicates absolute disagreement, (2) refers to counting approval, (3) means neutrality, (4) means approval, and (5) refers to absolute approval. The ladder has divided into three areas to determine the degree of evaluation as follows; 1 to less than 2.5 the field of low evaluation, from 2.5 to less than 3.5 the field of average evaluation, and from 3.5 to 5 the field of a high evaluation. The research is testing the conceptual framework as shown in the figure (1). Then, the hypotheses of the research as follows:

1. There is a correlation between the customer's trust and the perceived quality of food provided in the hotels at the 0.05 level. 
2. There is a correlation between the customer's trust and the customer's behavioral attitudes at the 0.05 level.

3. There is a correlation between the customer's trust and the customer's subjective norms at the 0.05 level.

4. There is a correlation between the customer's trust and the customer's perceived behavioral control at the 0.05 level.

5. There is a correlation between the customer's trust and the customer's behavioral intention at the 0.05 level.

Fig. 1: The Conceptual Framework of the Research

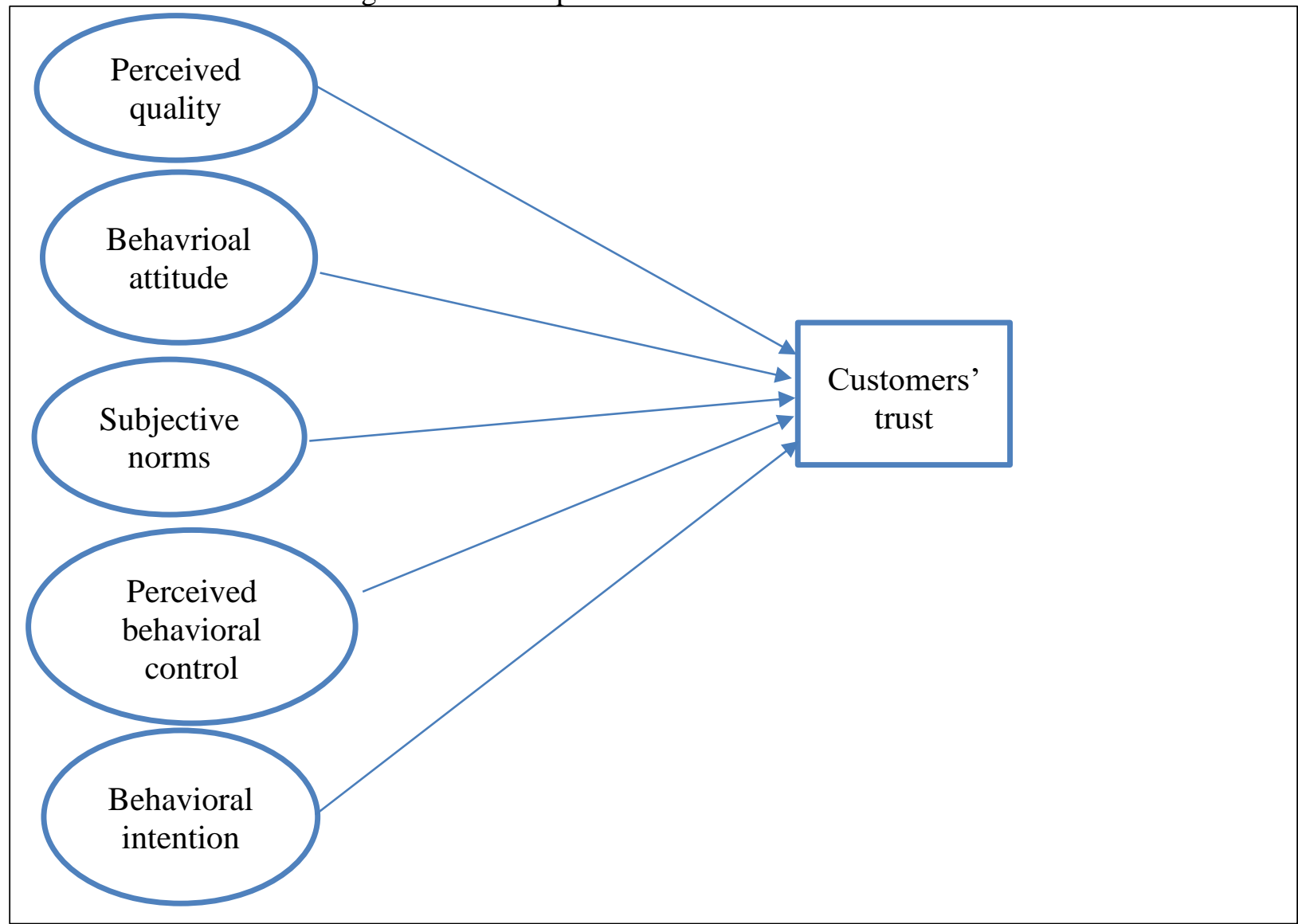

\section{Data Analysis and Results Discussion}

The following table 1 shows the statistical distribution for the scale of the level of customer trust in foods, using a Kolmogorov-Smirnov test

Table 1: The Normal Distribution of Research Variables

\begin{tabular}{|l|l|c|c|}
\hline No & \multicolumn{1}{|c|}{ Latent Variables } & Kolmogorov-Smirnov Test & Sig. \\
\hline 1 & Perceived Quality (PQ) & 0.150 & 0.000 \\
\hline 2 & Behavioral Attitudes (BA) & 0.204 & 0.000 \\
\hline 3 & Subjective Norms (SN) & 0.113 & 0.000 \\
\hline 4 & Perceived Behavioral Control (PBC) & 0.292 & 0.000 \\
\hline 5 & Behavioral Intention (BI) & 0.352 & 0.000 \\
\hline 6 & Customer's Trust (CT) & 0.46 & 0.016 \\
\hline
\end{tabular}

It can be inferred from the table 1 that the distribution of research variables is non-normal distribution. Therefore, the research depends on the non-parametric tests such as Mann-Whitney U and Kruskal-Wallis tests for measuring the differences among research variables. 
International Journal of Heritage, Tourism and Hospitality Vol. (14), No. (1), June, 2020

Table 2: The Demographic Data of Respondents

\begin{tabular}{|c|c|c|c|}
\hline Variable & Category & Frequency & Percent \\
\hline \multirow{3}{*}{ City } & Luxor & 266 & 54.1 \\
\hline & Aswan & 37 & 7.5 \\
\hline & Cairo & 189 & 38.4 \\
\hline \multirow[t]{8}{*}{ Nationality } & Egyptian & 83 & 16.9 \\
\hline & American & 13 & 2.6 \\
\hline & British & 142 & 28.9 \\
\hline & French & 81 & 16.5 \\
\hline & German & 70 & 14.21 \\
\hline & Italian & 47 & 9.6 \\
\hline & Polish & 13 & 2.6 \\
\hline & Other & 43 & 87.6 \\
\hline \multirow[t]{2}{*}{ Gender } & Male & 425 & 86.4 \\
\hline & Female & 67 & 13.6 \\
\hline \multirow[t]{4}{*}{ Age } & Below 18 & 50 & 10.21 \\
\hline & $18-32$ & 111 & 22.6 \\
\hline & $33-49$ & 249 & 50.6 \\
\hline & 50 and over & 82 & 16.7 \\
\hline \multirow[t]{2}{*}{ Marital Status } & Single & 214 & 43.5 \\
\hline & Married & 278 & 56.5 \\
\hline \multirow[t]{5}{*}{ Education Level } & Middle School & 36 & 7.3 \\
\hline & High School & 120 & 24.4 \\
\hline & Technical School & 75 & 15.2 \\
\hline & College Degree & 232 & 47.2 \\
\hline & Postgraduate & 29 & 5.9 \\
\hline \multirow[t]{5}{*}{ Family Size } & 1 Member & 13 & 2.6 \\
\hline & 2 Members & 278 & 56.5 \\
\hline & 3 Members & 183 & 37.2 \\
\hline & 4 Members & 16 & 2.4 \\
\hline & 5 Members or above & 6 & 1.2 \\
\hline
\end{tabular}

It is clear from the table 2 that most of the participants are male $(86.4 \%)$ and their ages ranged from 33 to 49 years old $(50.6 \%)$. They are married $(56.5 \%)$ with a family of two members $(56.5 \%)$, and most of them have a university degree (47.2\%). In addition, most of the participants stayed in Luxor hotels $(54.1 \%)$, and in Cairo hotels (38.4\%). Finally, their nationalities were represented in British (28.9\%), Egyptian (16.9\%), and French (16.5\%). The sample represents the majority of customers in the hotels of Cairo, Luxor, and Aswan.

Table 3: Familiarity with Different Certified Food Labels

\begin{tabular}{|l|l|l|l|l|l|l|}
\hline \multirow{2}{*}{ Items } & \multicolumn{6}{|c|}{ Familiarity with different certified food labels } \\
\cline { 2 - 7 } & $\begin{array}{c}\text { Egyptian } \\
\text { Organic Food }\end{array}$ & $\begin{array}{c}\text { Hazard- } \\
\text { Free Food }\end{array}$ & $\begin{array}{c}\text { Green } \\
\text { Food }\end{array}$ & $\begin{array}{c}\text { Chinese/Japanese } \\
\text { Organic Food }\end{array}$ & $\begin{array}{c}\text { USA Organic } \\
\text { Product }\end{array}$ & $\begin{array}{c}\text { EU Organic } \\
\text { Product }\end{array}$ \\
\hline $\begin{array}{l}\text { Have seen it } \\
\text { before }\end{array}$ & 87.2 & 21.3 & 100.0 & 59.8 & 21.7 & 26.8 \\
\hline $\begin{array}{l}\text { Have not seen } \\
\text { it before }\end{array}$ & 12.8 & 78.7 & 0 & 40.2 & 78.3 & 73.2 \\
\hline
\end{tabular}

Table 3 shows the level of familiarity with different certified food labels. It was revealed that green foods came at first rank with (100\%). This is consistent with many previous studies, which acknowledged that customers are moving towards green foods (IRI, 2003; Percsi \& Fogarassy, 2019; Ngo et al., 2020; Toth et al., 2020). This shift is due to the growth of nutrition-related diseases 
has become a concern and a challenge for a more sustainable society (Tóth et al., 2020). In addition, the current study revealed that organic foods represent the second rank such as Egyptian Organic Foods (0.872), Chinese/Japanese Organic Foods (0.598), EU Organic Product (0.268), and USA Organic Product (0.217). The third rank is represented in Hazard-Free Foods $(0.213)$. There has been a rapid rise in the global consumption of organic foods (IRI, 2003; Chu, 2018; Nguyen et al., 2019). This rapid increase is supported by food scandals that have swept the world, such as the use of horsemeat as beef (McCarthy, 2018). Consequently, about $87.2 \%$ of the consumers stated that Egyptian hotels offer organic foods, and this is a competitive advantage for these hotels.

Table 4: The Trust Level of Food Certification Bodies

\begin{tabular}{|l|c|c|c|c|c|}
\hline \multirow{2}{*}{ Food Certification Bodies } & \multicolumn{5}{|c|}{ Trust Level } \\
\cline { 2 - 6 } & $\begin{array}{c}\text { No } \\
\text { opinion }\end{array}$ & Trustworthy & $\begin{array}{c}\text { Highly } \\
\text { trustworthy }\end{array}$ & $\begin{array}{c}\text { Highly } \\
\text { untrustworthy }\end{array}$ & Untrustworthy \\
\hline International organizations & 0 & 0 & 100 & 0 & 0 \\
\hline Egyptian national government & 85.8 & 0 & 0 & 0 & 14.2 \\
\hline $\begin{array}{l}\text { Local universities and scientific } \\
\text { institutions }\end{array}$ & 0 & 0 & 0 & 0 & 100. \\
\hline
\end{tabular}

Depending on the table 4 , about $100 \%$ of respondents trust in international food certification organizations, and they do not trust in the local universities and institutes. With regard to the Egyptian official bodies, about $85.8 \%$ of them have no opinion, while $14.2 \%$ do not trust in these institutions. This requires these bodies to implement the quality standards to gain consumer trust in the food products. This result agreed with the study of Wang et al., (2020) which stated that nearly $70 \%$ of the respondents consider certification labels granted by international food safety organizations as the most reassuring guarantee of food safety and product quality.

Table 5: Descriptive Statistics of the Scale of Customers' Trust Level

\begin{tabular}{|c|c|c|c|c|c|c|}
\hline No & $\begin{array}{c}\text { Latent } \\
\text { variables }\end{array}$ & Manifest variables & Mean & Std. & $\begin{array}{l}\text { CV } \\
(\%)\end{array}$ & Evaluation \\
\hline \multirow[t]{3}{*}{1} & \multirow[t]{3}{*}{$\begin{array}{l}\text { Perceived } \\
\text { quality }\end{array}$} & $\begin{array}{l}\text { I agree that Egyptian foods with a safety } \\
\text { certificate have a better texture (Taste). }\end{array}$ & 3.67 & 1.348 & 0.37 & High \\
\hline & & $\begin{array}{l}\text { I agree that Egyptian foods with a safety } \\
\text { certificate have richer nutrition (Nutritional } \\
\text { Value) }\end{array}$ & 4.18 & 1.199 & 0.33 & High \\
\hline & & $\begin{array}{l}\text { I agree that Egyptian foods with a safety } \\
\text { certificate have higher reliability of having a } \\
\text { better quality (Reliability) }\end{array}$ & 4.11 & 0.772 & 0.21 & High \\
\hline \multirow[t]{5}{*}{2} & \multirow[t]{5}{*}{$\begin{array}{l}\text { Behavioral } \\
\text { attitudes }\end{array}$} & $\begin{array}{l}\text { Consumption of Egyptian foods with a } \\
\text { safety certificate is beneficial for me and my } \\
\text { family's health (Health) }\end{array}$ & 4.23 & 0.479 & 0.13 & High \\
\hline & & $\begin{array}{l}\text { Consumption of Egyptian foods with a } \\
\text { safety certificate is beneficial for the } \\
\text { sustainable development of the agricultural } \\
\text { industry (Development) }\end{array}$ & 4.13 & 0.809 & 0.22 & High \\
\hline & & $\begin{array}{l}\text { Purchasing Egyptian foods with a safety } \\
\text { certificate is beneficial for environmental } \\
\text { protection (Environment) }\end{array}$ & 4.60 & 1.033 & 0.28 & High \\
\hline & & $\begin{array}{l}\text { Purchasing Egyptian foods with a safety } \\
\text { certificate is a wise decision (Wise) }\end{array}$ & 4.27 & 0.447 & 0.12 & High \\
\hline & & $\begin{array}{l}\text { The adoption of the quality certification for } \\
\text { Egyptian foods can improve the product's } \\
\text { safety for consumption (Safe) }\end{array}$ & 4.22 & 0.465 & 0.13 & High \\
\hline
\end{tabular}


International Journal of Heritage, Tourism and Hospitality Vol. (14), No. (1), June, 2020

\begin{tabular}{|c|c|c|c|c|c|c|}
\hline No & $\begin{array}{c}\text { Latent } \\
\text { variables }\end{array}$ & Manifest variables & Mean & Std. & $\begin{array}{l}\text { CV } \\
(\%)\end{array}$ & Evaluation \\
\hline & & $\begin{array}{l}\text { The adoption of the quality certification can } \\
\text { improve consumers' confidence in the safety } \\
\text { of Egyptian foods they consume } \\
\text { (Confidence). }\end{array}$ & 4.90 & 0.412 & 0.11 & High \\
\hline & & $\begin{array}{l}\text { I support purchasing Egyptian foods with a } \\
\text { safety certificate (Support). }\end{array}$ & 4.92 & 0.443 & 0.12 & High \\
\hline \multirow[t]{7}{*}{3} & \multirow[t]{7}{*}{$\begin{array}{l}\text { Subjective } \\
\text { norms }\end{array}$} & $\begin{array}{l}\text { Family, relatives, and friends have a large } \\
\text { influence on my decision whether to } \\
\text { purchase Egyptian foods with certified } \\
\text { labels (Family) }\end{array}$ & 4.22 & 0.752 & 0.21 & High \\
\hline & & $\begin{array}{l}\text { Colleagues and my boss have a large } \\
\text { influence on my decision whether to } \\
\text { purchase Egyptian foods with certified } \\
\text { labels (Colleagues) }\end{array}$ & 4.05 & 1.121 & 0.31 & High \\
\hline & & $\begin{array}{l}\text { Sales promotions have a large influence on } \\
\text { my decision whether to purchase Egyptian } \\
\text { foods with certified labels (Sales) }\end{array}$ & 4.46 & 0.549 & 0.15 & High \\
\hline & & $\begin{array}{l}\text { Other consumers have a large influence on } \\
\text { my decision of whether to purchase } \\
\text { Egyptian foods with certified labels } \\
\text { (Consumers). }\end{array}$ & 2.32 & 0.992 & 0.27 & Low \\
\hline & & $\begin{array}{l}\text { Government Promotions and campaigns } \\
\text { have influence on my decision whether to } \\
\text { purchase Egyptian foods with certified } \\
\text { labels (Publicity). }\end{array}$ & 3.99 & 0.303 & 0.08 & High \\
\hline & & $\begin{array}{l}\text { Information from the media has a large } \\
\text { influence on my decision whether to } \\
\text { purchase Egyptian foods with certified } \\
\text { labels (Media) }\end{array}$ & 2.98 & 1.018 & 0.28 & Average \\
\hline & & $\begin{array}{l}\text { Opinions of experts and academics have a } \\
\text { large influence on my decision whether to } \\
\text { purchase Egyptian foods with certified } \\
\text { labels (Academics) }\end{array}$ & 4.18 & 0.757 & 0.21 & High \\
\hline \multirow[t]{5}{*}{4} & \multirow[t]{5}{*}{$\begin{array}{l}\text { Perceived } \\
\text { behavioral } \\
\text { control }\end{array}$} & $\begin{array}{l}\text { Means of purchasing Egyptian foods with } \\
\text { certified labels are } \\
\text { (Convenience) }\end{array}$ & 2.08 & 0.293 & 0.08 & Low \\
\hline & & $\begin{array}{l}\text { Features of Egyptian foods with certified } \\
\text { labels are not hard to identify (Distinguish) }\end{array}$ & 4.55 & 0.598 & 0.16 & High \\
\hline & & $\begin{array}{l}\text { I possess all the necessary conditions to } \\
\text { purchase Egyptian foods with certified labels } \\
\text { (Condition) }\end{array}$ & 4.17 & 0.536 & 0.15 & High \\
\hline & & $\begin{array}{l}\text { Cost of purchasing Egyptian foods with } \\
\text { certified labels did not increase remarkably } \\
\text { (Cost) }\end{array}$ & 3.81 & 0.450 & 0.12 & High \\
\hline & & $\begin{array}{l}\text { I am experienced enough to guarantee that } \\
\text { Egyptian foods which I purchase is safe for } \\
\text { consumption (Experience) }\end{array}$ & 4.95 & 0.211 & 0.06 & High \\
\hline 5 & $\begin{array}{l}\text { Behavioral } \\
\text { intention }\end{array}$ & $\begin{array}{l}\text { Willing to try purchasing Egyptian foods } \\
\text { with certified labels (Try) }\end{array}$ & 4.33 & 0.509 & 0.14 & High \\
\hline
\end{tabular}


International Journal of Heritage, Tourism and Hospitality Vol. (14), No. (1), June, 2020

\begin{tabular}{|c|c|l|c|c|c|c|}
\hline No & $\begin{array}{c}\text { Latent } \\
\text { variables }\end{array}$ & \multicolumn{1}{|c|}{ Manifest variables } & Mean & Std. & $\begin{array}{c}\text { CV } \\
(\mathbf{\%})\end{array}$ & Evaluation \\
\hline & & $\begin{array}{l}\text { Willing to pay for Egyptian foods with } \\
\text { certified labels with a high price (Price) }\end{array}$ & 3.82 & 0.498 & 0.14 & High \\
\cline { 2 - 7 } & $\begin{array}{l}\text { Willing to pay for Egyptian foods with } \\
\text { certified labels with a higher premium } \\
\text { (Range) }\end{array}$ & 4.08 & 0.264 & 0.07 & High \\
\hline \multicolumn{1}{|c|}{ Mean } & 4.0497 & 0.11483 & 0.028 & High \\
\hline
\end{tabular}

Table 5 shows the scale of customers' trust level of foods in the Egyptian hotels in Cairo, Luxor, and Aswan. This scale is designed by Wang et al., (2020), where they stated that the average values of the Cronbach's Alpha of all four latent variables are higher than 0.7 and fall in the range of acceptable reliability value, indicating good internal consistency within all these variables. In addition, most of the standard factor loadings of the manifest variables are higher than 0.6. Consequently, the latent variables have good convergent validity and are suitable and sufficient for further data analysis. It is clear from the table (5) that most of the research manifest variables are the highest levels ranging from 3.5 to 5, and some of them are the lowest levels ranging from 1 to less than 2.5, and these variables include consumers and convenience. The media variable (2.98) is a medium level. This requires improving the factors of consumers, convenience, and media in order to increase customer trust in the Egyptian foods. In addition, the coefficient of variation is high for the factors of taste, nutritional value, and colleagues, while it is low for the factors of publicity, convenience, range, and experience. The previous studies revealed that the overall reliability of service providers have an important component of perceived quality and have a direct impact on the intention to purchase (Chen and Chen, 2011). Then, the dissemination of food safety information is an effective intervention tool that positively affects food safety behaviors for food processors (Chapman et al., 2010).

Table 6: Descriptive Statistics for Latent Variables of Customers' Trust Level

\begin{tabular}{|l|l|l|c|c|c|}
\hline No & \multicolumn{1}{|c|}{ Latent Variables } & Mean & Std. & CV (\%) & Evaluation \\
\hline 1 & Perceived quality & 3.9885 & 0.61922 & 0.16 & High \\
\hline 2 & Behavioral attitudes & 4.4681 & 0.19771 & 0.05 & High \\
\hline 3 & Subjective norms & 3.7445 & 0.29276 & 0.073 & High \\
\hline 4 & Perceived behavioral control & 3.9122 & 0.20605 & 0.05 & High \\
\hline 5 & behavioral intention & 4.0766 & 0.21009 & 0.05 & High \\
\hline 6 & customer's trust & 4.0380 & 0.13552 & 0.028 & High \\
\hline
\end{tabular}

According to the table 6, the mean of customers' trust level for the foods of Egyptian hotels is (4.04); it is referring to the high level of customers' trust. In addition, the standard deviation is 0.136. Therefore, the coefficient of variance is 0.028 . The factor of behavioral attitudes ranked first (4.5), followed by behavioral intention (4.1), perceived quality (4), perceived behavioral control (3.91), and subjective norms (3.74). Moreover, the coefficient of variance (CV) was high at the perceived quality factor (0.16) compared to the rest of the variables. This requires improving the quality of Egyptian foods to ensure a higher level of customer trust. This research has determined that customers have a high level of trust in the food served in hotels. This result is very important because the customers' trust is the vital variable that customers take into account when purchasing foods (Chaaban, 2012; Ricci et al., 2018). Consequently, sustainable labeling is an important tool in raising awareness and informing potential buyers on environmental, economic, and social issues (Kaczorowska et al., 2019). The results of the current study disagree with the studies of Xiong et al., (2011) and Labelinsight (2016), which they stated that consumers do not trust the way current brands provide them with product information. 
International Journal of Heritage, Tourism and Hospitality Vol. (14), No. (1), June, 2020

Table 7: The Frequency of Research Manifest Variables

\begin{tabular}{|c|c|c|c|c|c|c|c|}
\hline \multirow{2}{*}{ No } & \multirow{2}{*}{$\begin{array}{c}\text { Latent } \\
\text { variables }\end{array}$} & \multirow{2}{*}{$\begin{array}{l}\text { Manifest } \\
\text { variables }\end{array}$} & \multicolumn{5}{|c|}{ Evaluation level (\%) } \\
\hline & & & Strongly agree & Agree & Neutral & Disagree & Strongly disagree \\
\hline \multirow[t]{3}{*}{1} & \multirow{3}{*}{$\begin{array}{l}\text { Perceived } \\
\text { quality }\end{array}$} & Taste & 32.9 & 36.2 & 8.5 & 10.2 & 12.2 \\
\hline & & $\begin{array}{l}\text { Nutritional } \\
\text { Value }\end{array}$ & 60.8 & 11.0 & 20.5 & 0.8 & 6.9 \\
\hline & & Reliability & 26.0 & 66.3 & 3.5 & 1.4 & 2.8 \\
\hline \multirow[t]{7}{*}{2} & \multirow{7}{*}{$\begin{array}{l}\text { Behavioral } \\
\text { attitudes }\end{array}$} & Health & 25.4 & 72.0 & 2.6 & 0 & 0 \\
\hline & & Development & 38.2 & 38.4 & 21.5 & 1.8 & 0 \\
\hline & & Environment & 83.9 & 4.5 & 3.5 & 3.7 & 4.5 \\
\hline & & Wise & 27.4 & 72.6 & 0 & 0 & 0 \\
\hline & & Safe & 24.2 & 73.6 & 2.2 & 0 & 0 \\
\hline & & Confidence & 94.3 & 1.6 & 4.1 & 0 & 0 \\
\hline & & Support & 96.5 & 1.2 & .8 & 1.0 & 0.4 \\
\hline \multirow[t]{7}{*}{3} & \multirow{7}{*}{$\begin{array}{l}\text { Subjective } \\
\text { norms }\end{array}$} & Family & 39.8 & 43.5 & 15.4 & 1.0 & 0.2 \\
\hline & & Colleagues & 42.3 & 38.6 & 7.1 & 6.3 & 5.7 \\
\hline & & Sales & 48.6 & 48.8 & 2.6 & 0 & 0 \\
\hline & & Consumers & $\varepsilon, V$ & 10.6 & 10.6 & 60.6 & 13.6 \\
\hline & & Publicity & 2.6 & 95.3 & 1.2 & 0.4 & 0.4 \\
\hline & & Media & 11.8 & 14.0 & 36.2 & 36.6 & 1.4 \\
\hline & & Academics & 33.1 & 57.1 & 5.9 & 2.6 & 1.2 \\
\hline \multirow[t]{5}{*}{4} & \multirow{5}{*}{$\begin{array}{l}\text { Perceived } \\
\text { behavioral } \\
\text { control }\end{array}$} & Convenience & 0 & 0 & 0.8 & 90.9 & 0.8 \\
\hline & & Distinguish & 60.0 & 36.0 & 3.7 & 0.2 & 0.2 \\
\hline & & Condition & 23.8 & 69.1 & 7.1 & 0 & 0 \\
\hline & & Cost & 1.6 & 78.7 & 18.9 & 0.8 & 0 \\
\hline & & Experience & 95.3 & 4.7 & 0 & 0 & 0 \\
\hline \multirow[t]{3}{*}{5} & \multirow{3}{*}{$\begin{array}{l}\text { Behavioral } \\
\text { intention }\end{array}$} & Try & 35.0 & 63.2 & 1.8 & 0 & 0 \\
\hline & & Price & 5.1 & 72.2 & 22.8 & 0 & 0 \\
\hline & & Range & 7.5 & 92.5 & 0 & 0 & 0 \\
\hline
\end{tabular}

Table 7 shows the frequency of research manifest variables. It appears that $92.3 \%$ of the participants strongly agree with the reliability of food products served in hotels. This is due to the overall reliability of service providers have an important component of perceived quality and have a direct impact on the intention to purchase (Chen and Chen, 2011). In addition, the current study stated that $96 \%$ of participants strongly agree with the trust of food products. The previous studies stated that the customer's trust is a vital element in the functioning of any market, particularly the food and beverage sector.

Table 8: The Relationships between Research Manifest Variables

\begin{tabular}{|c|c|c|c|}
\hline Variables $(\mathrm{X})$ & Variables (Y) & $\mathbf{R}$ & Sig \\
\hline Perceived quality & \multirow[t]{5}{*}{ Customers' Trust } & $0.794^{* *}$ & 0.000 \\
\hline Behavioral attitudes & & $0.104^{*}$ & 0.021 \\
\hline Subjective norms & & $0.426^{* *}$ & 0.000 \\
\hline Perceived behavioral control & & $0.192^{* *}$ & 0.000 \\
\hline Behavioral intention & & 0.006 & 0.886 \\
\hline Perceived quality & \multirow{4}{*}{$\begin{array}{l}\text { Customers' } \\
\text { purchase intention }\end{array}$} & -0.393 & 0.000 \\
\hline Behavioral attitudes & & -0.008 & 0.867 \\
\hline Perceived behavioral control & & 0.011 & 0.802 \\
\hline Subjective norms & & 0.126 & 0.005 \\
\hline
\end{tabular}

**Correlation is significant at the 0.01 level (2-tailed); *Correlation is significant at the 0.05 level (2-tailed). 
It is shown from table (8) that customers' trust of foods correlated with the perceived quality $(\mathrm{r}=$ $0.794)$, behavioral attitudes $(r=0.104)$, subjective norms $(r=0.426)$ and perceived behavioral control $(r=0.192)$. There is no significant correlation between overall customers' trust and behavioral intention. In addition, there is a positive correlation between subjective norms and customers' purchase intention. On the contrary, there is a negative correlation between perceived quality and customers' purchase intention. In addition, there is no significant correlation between the customers' purchase intention and the research variables such as behavioral attitudes and perceived behavioral control. This research agreed with the study of Wang et al., (2020), which determined that the perceived quality affects the customers' purchase intention. Consequently, the results of this study revealed the model of customer's trust. Figure (2) shows the model of customer's trust and its variables.

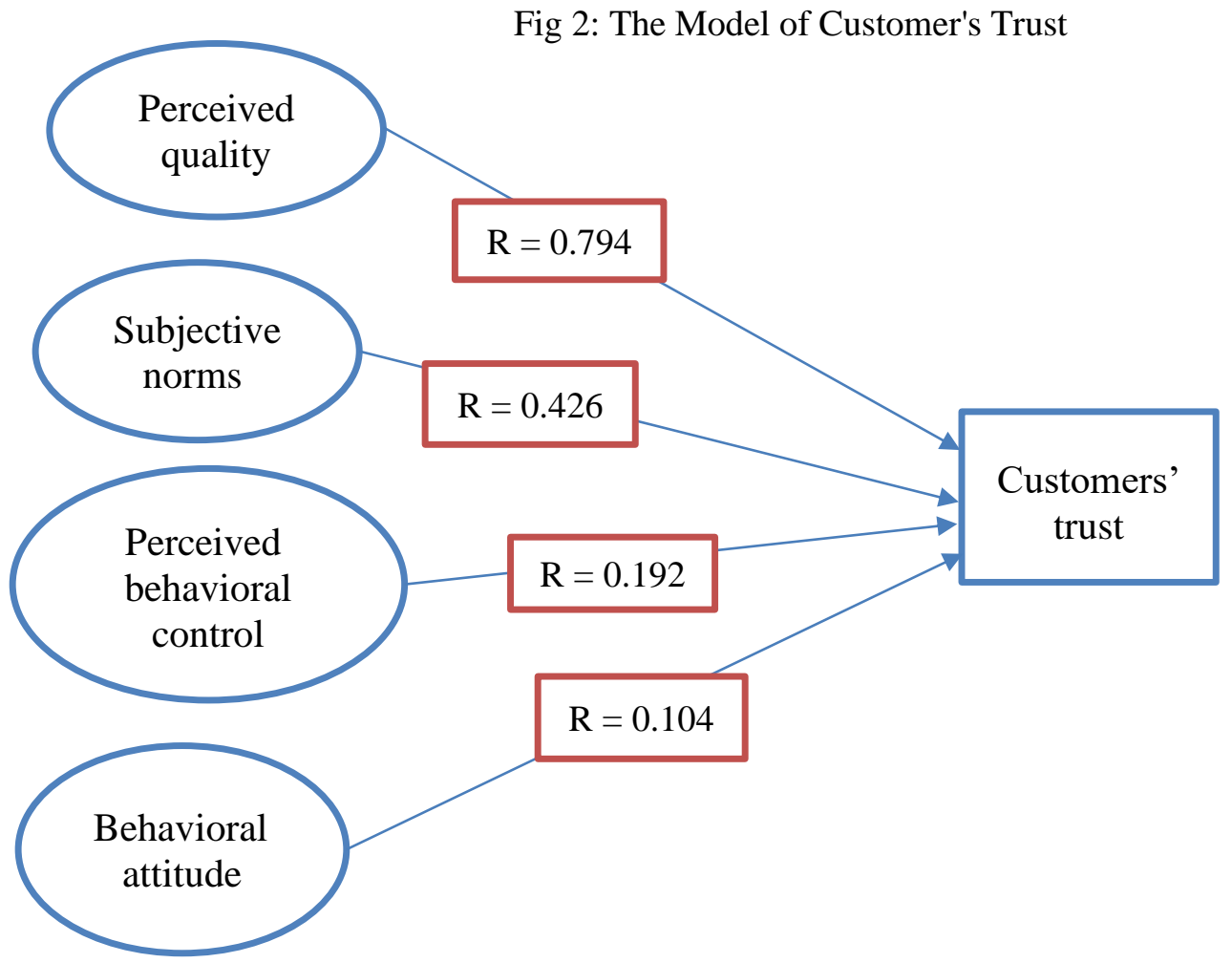

Table (9): The Customer's Trust level across Demographic Information

\begin{tabular}{|c|c|c|c|c|c|c|c|}
\hline Variable & Category & Levels & Mean Rank & Test & Statistic & df & Sig \\
\hline \multirow{14}{*}{$\begin{array}{l}\text { Customer's } \\
\text { Trust }\end{array}$} & \multirow[t]{3}{*}{ City } & Luxor & 230.16 & \multirow{11}{*}{$\begin{array}{l}\text { Kruskal- } \\
\text { Wallis H }\end{array}$} & \multirow[t]{3}{*}{27.457} & \multirow[t]{3}{*}{2} & \multirow[t]{3}{*}{0.000} \\
\hline & & Aswan & 170.64 & & & & \\
\hline & & Cairo & 284.35 & & & & \\
\hline & \multirow[t]{8}{*}{ Nationality } & Egyptian & 367.74 & & \multirow[t]{8}{*}{80.304} & \multirow[t]{8}{*}{7} & \multirow[t]{8}{*}{0.000} \\
\hline & & American & 219.04 & & & & \\
\hline & & British & 222.97 & & & & \\
\hline & & French & 245.64 & & & & \\
\hline & & German & 230.79 & & & & \\
\hline & & Italian & 214.78 & & & & \\
\hline & & Polish & 196.77 & & & & \\
\hline & & Other & 175.38 & & & & \\
\hline & \multirow[t]{2}{*}{ Gender } & Male & 233.60 & Mann- & \multirow{2}{*}{\multicolumn{2}{|c|}{8756.00}} & \multirow[t]{3}{*}{0.000} \\
\hline & & Female & 328.31 & Whitney U & & & \\
\hline & Age & Below 18 & 155.26 & Kruskal- & 26.305 & 3 & \\
\hline
\end{tabular}




\begin{tabular}{|c|c|c|c|c|c|c|c|}
\hline Variable & Category & Levels & Mean Rank & Test & Statistic & df & Sig \\
\hline & & $18-32$ & 261.84 & \multirow[t]{15}{*}{ Wallis $\mathrm{H}$} & & & \multirow[t]{3}{*}{0.000} \\
\hline & & $33-49$ & 263.15 & & & & \\
\hline & & 50 and over & 230.81 & & & & \\
\hline & \multirow{2}{*}{$\begin{array}{l}\text { Marital } \\
\text { Status }\end{array}$} & Single & 267.64 & & \multirow[t]{3}{*}{8.376} & \multirow[t]{3}{*}{1} & \multirow[t]{3}{*}{0.004} \\
\hline & & Married & 230.23 & & & & \\
\hline & \multirow[t]{5}{*}{$\begin{array}{l}\text { Education } \\
\text { Level }\end{array}$} & $\begin{array}{l}\text { Middle } \\
\text { School }\end{array}$ & 197.35 & & & & \\
\hline & & High School & 264.38 & & \multirow[t]{4}{*}{16.826} & \multirow{4}{*}{4} & \multirow[t]{4}{*}{0.002} \\
\hline & & $\begin{array}{l}\text { Technical } \\
\text { School }\end{array}$ & 204.41 & & & & \\
\hline & & $\begin{array}{l}\text { College } \\
\text { Degree }\end{array}$ & 262.15 & & & & \\
\hline & & Postgraduate & 217.17 & & & & \\
\hline & \multirow{5}{*}{$\begin{array}{l}\text { Family } \\
\text { Size }\end{array}$} & 1 Member & 282.08 & & \multirow[t]{5}{*}{2.442} & \multirow[t]{5}{*}{4} & \multirow[t]{5}{*}{0.655} \\
\hline & & 2 Members & 243.14 & & & & \\
\hline & & 3 Members & 250.25 & & & & \\
\hline & & 4 Members & 260.67 & & & & \\
\hline & & $\begin{array}{l}\text { 5.Members } \\
\text { \& More }\end{array}$ & 182.25 & & & & \\
\hline
\end{tabular}

Through a table (9), there are statistically significant differences for the level of customer's trust for Egyptian foods for the factors of city, nationality, gender, age, marital status, and education level at a significant level of 0.05 . While there is no statistically significant difference according to the family size factor (Sig. · 755). The results of this research are agreed with the previous studies that stated that attitude and behavioral outcomes of the customer's trust alter are based on the demographic characteristics and the nationality of customers (Al-Ansi et al., 2020).

Table (10): The Level of Customer's Trust According to Brands Types

\begin{tabular}{|l|l|l|c|c|c|}
\hline Variable & \multicolumn{1}{|c|}{ Category (Brands Types) } & Mean Rank & Test & Statistic & Sig. \\
\hline \multirow{3}{*}{$\begin{array}{l}\text { Customer's } \\
\text { Trust }\end{array}$} & International Organizations & 1230.50 & Kruskal- & 1384.542 & 0.000 \\
\cline { 2 - 3 } & Egyptian National Government & 703.50 & Wallis H & & \\
\cline { 2 - 3 } & $\begin{array}{l}\text { Local Universities and } \\
\text { Scientific Institutions }\end{array}$ & 281.50 & & & \\
\hline
\end{tabular}

It is clear from table (10) that the level of customer trust varies significantly (Sig 0.00) according to the brands. According to the previous studies, most customers prefer the food products of international organizations (Wang et al., 2020).

\section{Conclusion}

This study aims to measure the level of customer's trust in the food products provided in the hotels of Cairo, Luxor, and Aswan. The results of this study showed that most of the participants are male (86.4\%), ranging in age from 33 to 49 years by $56.5 \%$, they are married $(56.5 \%)$, have a family consisting of two members $(56.5 \%)$ and have a university degree $(47.2 \%)$. In addition, about $54.1 \%$ of participants stayed in the hotels of Luxor, 38.4\% in Cairo hotels, and $7.5 \%$ in Aswan hotels. About 100 of the participants in this study prefer green food, 87.2\% prefer Egyptian organic foods, $59.8 \%$ Japanese/Chinese organic foods, 26.8\% European organic foods, $21.7 \%$ American organic foods, and $21.3 \%$ risk-free foods. About $100 \%$ of the participants trust in the foods of international institutions, while they do not trust the foods of local universities and institutes. Almost $85.8 \%$ of the participants did not make any evaluation of the food produced by the Egyptian institutions, while $14.2 \%$ do not trust the food of these institutions. This requires those institutions to improve their system and implement quality standards to obtain customer trust in these products. Based on 
the results of this study, the level of customer trust in foods served inside the hotels of Cairo, Luxor, and Aswan is considered a high level. In addition, the coefficient of variance is $2.8 \%$. This level varies according to the factors of the hotel's location, the nationality of the participants, age, gender, marital status, educational level, and the type of food establishments at the level of 0.05 , while it does not differ according to the family size. Moreover, the level of customer trust is positive related to the variables of perceived quality, behavioral attitudes, subjective norms, and perceived behavioral control. In addition, there is no relationship between the level of customer trust and behavioral intention, while there is a positive correlation between the intention of purchase and objective norms. Moreover, there is no significant correlation between the customers' purchase intention and the research variables such as behavioral attitudes and perceived behavioral control.

\section{Recommendations}

Based on the previous results, this study provides a set of recommendations that would help in the topic of customer trust in the food provided in the hotels of Cairo, Luxor and Aswan as follows:

1. Hotels must adhere to the food and beverage labels by including and displaying all the detailed information about the food and its components, calories, quality, preservatives, fresh purity, safety, taste, and price.

2. The Food Safety Authority should provide hotels by the certified food labels that get the trust of the foreign customers in terms of food safety.

3. Hotels must use modern methods to assess the quality and safety of food and beverage products through committees of independent and impartial experts.

4. Hotels must adopt the principle of transparency in providing food and beverage services to customers.

5. Hotels must use free salt label, free fats, halal food and freshness label of food and beverage

6. Hotels should pay attention to organic foods due to customers' preference for these products. This gives hotels a competitive advantage that helps them attract the largest number of customers

7. The Egyptian Ministry of Tourism must obligate hotels to use approved and reliable food products for customers. In addition, conduct periodic inspections to ensure that this aim is achieved.

\section{Limitations and Future Researches}

The aim of this study was to measure the level of customer trust in the food products that are offered in the hotels of Cairo, Luxor and Aswan. Since the sample size is not large, therefore it is not possible to generalize the results of this study to all Egyptian hotels. Therefore, it is preferable to conduct this study in different regions in Egypt and focus on a larger number of customers.

\section{References}

Al-Ansi, A., Olya, G., \& Han, H., (2019). Effect of general risk on trust, satisfaction, and recommendation intention for halal food. International Journal of Hospitality Management, 83, 210-219.

Bai, L., Wang, M., \& Gong, S., (2019). Understanding the Antecedents of Organic Food Purchases: The Important Roles of Beliefs, Subjective Norms, and Identity Expressiveness. Sustainability, 11(11), 1-18.

Bandara, B., Silva, D., Maduwanthi, B., \& Warunasinghe, W., (2016). Impact of food labeling information on consumer purchasing decision: with special reference to faculty of Agricultural Sciences. Procedia Food Science, 6, 309-313

Basarir, A., \& Sherif, S., (2012). Consumers' awareness of food labeling: A case study of United Arab Emirates. African Journal of Agricultural Research, 7(28), 4021-4028. 
Benson, T., Lavelle, F., Spence, M., Elliott, T., \& Dean, M., (2020). The development and validation of a toolkit to measure consumer trust in food. Food Control, 110, https://doi.org/10.1016/j.foodcont.2019.106988

Božič, B., Siebert, S., \& Martin, G., (2020). A grounded theory study of factors and conditions associated with customer trust recovery in a retailer. Journal of Business Research, 109, 440448

Chaaban, J., (2012). The Efficiency of Food Labeling as a Rural Development Policy: The Case of Olive Oil in Lebanon, Issam Fares Institute for Public Policy and International Affairs; Working Paper Series.

Chapman, B., Eversley, T., Fillion, K., \& Maclaurin, T., (2010). Assessment of Food Safety Practices of Food Service Food Handlers (Risk Assessment Data): Testing a Communication Intervention (Evaluation of Tools). Jourmal of Food Protection, 73(6), 1101-1107.

Chen, Y., \& Chen, L., (2011). Empirical study on factual dimensions of consumer perceived value: take mobile service consumption as an example, Journal of Beijing University of posts and telecommunications. 13(3), 63-71.

Chu, K., (2018). Mediating Influences of Attitude on Internal and External Factors Influencing Consumers' Intention to Purchase Organic Foods in China. Sustainability, 10, (12).

Daugbjerg, C., Smed, S., Anderson, M., \& Schvartzman, Y., (2014). Improving eco-labeling as an environmental policy instrument: Knowledge, trust and organic consumption. Journal of Environmental Policy and Planning, 1(17), 559-575.

FAO (2016). Handbook on Food Labeling to Protect Consumers

FMI, (2003). Trends in the United States: Consumer attitudes and the supermarket", Food Marketing.

Gerrard, C., Janssen, M., Smith, L., Hamm, U. \& Padel, S., (2013). UK consumer reactions to organic certification logos. British Food Journal, 115(5),727-742.

IRI, (2003), Meals demise, snacks arise: Consumer redefines the American meal.

Jeong, Y., \& Ham, S., (2018). Application of the Health belief model to customers' use of menu labels in restaurants. Appetite, 123. 208-215.

Jonell, M., Crona, B., Brown, K., Rönnbäck, P., \& Troell, M., (2016). Eco-Labeled Seafood: Determinants for (Blue) Green Consumption. Sustainability, 8, (9). https://doi.org/10.3390/su8090884

Kaczorowska, J., Rejman, K., Halicka, E., Szczebyło, A., \& Warsewicz, H., (2019). Impact of Food Sustainability Labels on the Perceived Product Value and Price Expectations of Urban Consumers. Sustainability, 11(24). https://doi.org/10.3390/su11247240

Kang, W., \& Namkung, Y. (2019). The information quality and source credibility matter in customers' evaluation toward food $\mathrm{O} 2 \mathrm{O}$ commerce. International Journal of Hospitality Management, 78, 189-198

Kim, E., Tang, R., Meusel, C., \& Gupta, M. (2018). Optimization of menu-labeling formats to drive healthy dining: An eye tracking study. International Journal of Hospitality Management, 70, 3748

Konuk, A., (2019). Consumers' willingness to buy and willingness to pay for fair trade food: The influence of consciousness for fair consumption, environmental concern, trust and innovativeness. Food research international, 120, 141-147.

Labelinsight, (2016). How Consumer Demand for Transparency is shaping the Food Industry.

Lang, M., \& Lemmerer, A., (2019). How and why restaurant patrons value locally sourced foods and ingredients. International Journal of Hospitality Management, 77, 76-88. 
Le, A., Nguyen, M., Vu, H., \& Thi, T., (2020). Consumers' trust in food safety indicators and cues: the case of Vietnam. Food Control, 112. https://doi.org/10.1016/j.foodcont.2020.107162

Mandle, J., Tugendhaft, A., Michalow, J., \& Hofman, K., (2015). Nutrition labeling: a review of research on consumer and industry response in the global South. Global Health Action, 8, https://doi.org/10.3402/gha.v8.25912

McCarthy, E., (2018), Regaining Consumer Trust in the Food and Beverage Industry.

Nayga, R., Lipinski, D., \& Savur, N., (1998). Consumers' Use of Nutritional Labels While Food Shopping and At Home. Journal of Consumer Affairs,32(1),106-120.

Ngo, M., Liu, R., Moritaka, M., \& Fukuda, S., (2020). Urban consumer trust in safe vegetables in Vietnam: The role of brand trust and the impact of consumer worry about vegetable safety. Food Control, 108, https://doi.org/10.1016/j.foodcont.2019.106856.

Nguyen, H., Nguyen, N., Nguyen, B., Lobo, A., \& Vu, P., (2019). Organic Food Purchases in an Emerging Market: The Influence of Consumers' Personal Factors and Green Marketing Practices of Food Stores. Int. J. Environ. Res. Public Health, 16(6), https://doi.org/10.3390/ijerph16061037.

Nunes, K., (2019), Consumer expectations moving beyond the label

Pércsi, K., \& Fogarassy, C., (2019). Important Influencing and Decision Factors in Organic Food Purchasing in Hungary. Sustainability, 11(21) https://doi.org/10.3390/su11216075.

Peters, K., \& Remaud, H., (2020). Factors influencing consumer menu-item selection in a restaurant context. Food Quality and Preference, 82, https://doi.org/10.1016/j.foodqual.2020.103887

Prathiraja, K., \& Ariyawardana, A., (2003). Impact of nutritional labeling on consumer buying behavior. Sri Lankan Journal of Agricultural Economics, 5(1), 35-46

Rhou, Y., \& Singal, M., (2020). A review of the business case for CSR in the hospitality industry. International Journal of Hospitality https://doi.org/10.1016/j.ijhm.2019.102330.

Ricci, C., Banterle, A., \& Stranieri, S., (2018). Trust to go green: an exploration of consumer intentions for eco-friendly convenience food. Ecological economics, 48, 54-65

Rousseau, M., Sitkin, B., Burt, S., \& Camerer, C., (1998). Not so different after all: A crossdiscipline view of trust. Academy of management review, 23, 393-404.

Rupprecht, D., Fujiyoshi, L., McGreevy, R., \& Tayasu, I., (2020). Trust me? Consumer trust in expert information on food product labels. Food and Chemical Toxicology, 137. https://doi.org/10.1016/j.fct.2020.111170

Saad, N., Elgazzar, S., \& Saleh, G., (2016). The Impact of Implementing European Quality Labeling System on the Supply Chain Performance of Food Industry: An Empirical Study of the Egyptian Traditional Food Sector, International Journal of Economics and Management Engineering, 10(9), 3161-3162.

Shangguan, S., Afshin, A., Shulkin, M., \& Mozaffarian, D., (2016). Meta-Analysis of Food Labeling Effects on Consumer Diet Behaviors and Industry Practices. American Journal of Preventive Medicine, 56(2), 300-314.

Sloan, A., (2003). What consumers want-and don't want-on food and beverage labels. Food technology, 57(11), $26-30$.

Sultan, P., Tarafder, T., Pearson, D., \& Henryks, J., (2020). Intention-behavior gap and perceived behavioral control-behavior gap in theory of planned behavior: moderating roles of communication, satisfaction and trust in organic food consumption. Food Quality and Preference, 81, https://doi.org/10.1016/j.foodqual.2019.103838

Tóth, J., Migliore, G., Schifani, G., \& Rizzo, G., (2020). Sustainable Value Creation in the Food Chain: A Consumer Perspective. Sustainability, 12(4), 4-5 
Tuv-Nord (2020), ISO 22000 - Food Safety Management System.

Vecchio, R., \& Cavallo, C., (2019). Increasing healthy food choices through nudges: A systematic review. Food Quality and Preference, 78, https://doi.org/10.1016/j.foodqual.2019.05.014.

Vitale, S., Biondo, F., Giosue, C., Bono, G., Okpala, C., Piazza, I., Sprovieri, M., \& Pipitone, V., (2020). Consumers' Perception and Willingness to Pay for Eco-Labeled Seafood in Italian Hypermarkets. Sustainability, 12(4). https://doi.org/10.3390/su12041434

Vizcaíno, V., \& Velasco, A., (2019). The battle between brands and nutritional labels: How brand familiarity decreases consumers' alertness toward traffic light nutritional labels. Journal of Business Research, 101, 637-650.

Wang, J., Tao, J., \& Chu, M. (2020). Behind the label: Chinese consumers' trust in food certification and the effect of perceived quality on purchase intention. Food Control, 108. https://doi.org/10.1016/j.foodcont.2019.106825.

Xie, B., Wang, Y., Yang, H., Wang, H., \& Zhang, L., (2015). Consumer perceptions and attitudes of organic food products in Eastern China. British Food Journal, 117(3), 1105-1121.

Xiong, et al., (2011). An analysis on factors affecting the purchasing intention on pollution-free agricultural items: A survey study based on Kunming residences. Anhui agricultural science, 39(33), 800-801.

Yin, S., Wu, L., Du, L., \& Chen, M., (2010). Consumers' purchase intention of organic food in China. Journal of the science of food and agriculture, 90, 1361-1367.

$\mathrm{Yu}, \mathrm{X}$., et al., (2013) Consumers' cognitive consumption behavior towards middle, high-end pork and factors affecting purchasing intention: A study based on urban-Beijing residence. Chinese journal on animal husbandry, 49(12), 24-29.

Zhou, J., Liu, Q., Mao, R., \& Yu, H., (2017). Habit spillovers or induced awareness: willingness to pay for eco-labels of rice in China. Food Policy, 71, 62 -73. 